\title{
PEMBERDAYAAN PELAKU UMKM MERESPON PERGESERAN KARATERISTIK KONSUMEN DI ERA DIGITAL
}

\section{(UMKM EMPOWERMENT IN RESPONDING SHIFTING OF CONSUMER CHARACTERISTICS IN DIGITAL ERA)}

\author{
Sutinah $^{1}$, Bagong Suyanto ${ }^{2}$, Ratna Azis Prasetyo ${ }^{3}$ \\ 1,2,3 Departemen Sosiologi, Fakultas Ilmu Sosial dan Ilmu Politik, Universitas Airlangga \\ e-mail: sutinah@fisip.unair.ac.id
}

\begin{abstract}
The growth of Usaha Mikro, Kecil dan Menengah (UMKM) is able to reduce unemployment and poverty in Indonesia MSMEs can create new jobs and create new work units that use new personnel, so as to support household income. Therefore, UMKM Managers and actors must keep up with technology, so that the marketing and product promotion concepts that are implemented are widespread and attractive among buyers both at the domestic, regional and international levels. strategic. Especially with the enactment of the ASEAN Economic Community (MEA), Indonesian UMKM increasingly have greater market access. This activity is intended to empower local UMKM actors in Tuban Regency. The participants in this empowerment activity were as many as 50 people and were carried out by lecturing, discussion, training and mentoring in product marketing using digital technology. As a result of the community service activities, participants were enthusiastic about the activities carried out and proposed concrete follow-up actions such as training and mentoring in marketing digital-based products.
\end{abstract}

Keywords: Digital Marketing, ICT, UMKM

\section{abstrak}

Pertumbuhan Usaha Mikro, Kecil dan Menengah (UMKM) mampu mengurangi angka pengangguran dan kemiskinan di Indonesia. UMKM dapat menciptakan lapangan kerja baru dan unit-unit kerja baru menggunakan tenaga-tenaga baru, sehingga dapat mendukung pendapatan rumah tangga. Karena itu, Para pengelola dan pelaku UMKM harus mengikuti perkembangan teknologi, sehingga konsep pemasaran dan promosi produk yang dilaksanakan tersebar luas dan menarik dikalangan pembeli baik domestik, regional maupun internasional. UMKM di era digital sebagai motor penggerak perekonomian Indonesia, maka menjadi sangat strategis. Apalagi dengan telah berlakunya Masyarakat Ekonomi ASEAN (MEA), UMKM Indonesia semakin memiliki akses pasar yang lebih besar. Kegiatan ini dimaksudkan untuk memberdayakan para pelaku UMKM lokal di Kabupaten Tuban. Peserta dalam kegiatan pemberdayaan ini sebanyak 50 orang dan dilakukan dengan metode ceramah, diskusi, pelatihan dan pendampingan dalam pemasaran produk menggunakan teknologi digital. Hasil dari kegiatan pengabdian masyarakat ini peserta antusias dengan kegiatan yang dilakukan dan mengusulkan adanya tindak lanjut yang konkrit seperti pelatihan dan pendampingan dalam memasarkan produk berbasis digital.

Kata kunci: ICT, Pemasaran Digital, UMKM 


\section{PENDAHULUAN}

Di negara berkembang seperti Indonesia, usaha mikro, kecil dan menengah (UMKM) merupakan salah satu tulang punggung ekonomi negara. Namun demikian, di era perkembangan perekonomian informasional yang makin massif, harus diakui upaya untuk terus mendorong perkembangan UMKM tentu tak lepas dari masalah. Permasalahan yang kerap ditemui, banyak dari pelaku UMKM masih belum atau enggan mengenal teknologi internet untuk mendukung mengembangkan usahanya. Padahal pemanfaatan teknologi, informasi, dan jaringan internet semakin mudah dijangkau dan digunakan --bahkan untuk orang awam sekalipun. Di berbagai daerah, kita tidak menutup mata bahwa penggunaan teknologi informasi dalam lima tahun terakhir telah makin memasyarakat. Penggunaan TI kini tidak lagi hanya menjadi monopoli masyarakat golongan kelas menengah ke atas, melainkan telah benar-benar meluas hingga lapisan masyarakat yang paling bawah sekali pun.

Di berbagai daerah, termasuk di Kabupaten Tuban ditengarai masih banyak pemilik UMKM yang belum memahami arti penting Teknologi Informasi dan Komunikasi atau ICT (Information and Communications Technology), masih bingung dengan berbagai istilah-istilah teknologi dan cenderung beranggapan bahwa pemakaian teknologi informasi hanya cocok untuk perusahaan besar. Akibatnya, alih-alih mempergunakan dan memanfaatkan internet, dalam kenyataan hampir semua pelaku UMKM yang masih gagap dan hanya memanfaatkan TI dan internet untuk hal-hal yang sifatnya pleasure.

Untuk mendorong peningkatan pangsa pasar dan kinerja UMKM di Kabupaten Tuban, salah satu langkah dukungan yang mendesak untuk dikembangkan dan disosialisasikan kepada para pelaku UMKM adalah upaya pemberdayaan pelaku UMKM. Pemberdayaan pelaku UMKM ini perlu dilakukan, karena tiga alasan berikut. Pertama, karena para pelaku UMKM di Kabupaten Tuban ditengarai masih belum menguasai dengan baik mekanisme pemasaran produk yang sesuai dengan tuntutan pasar di era postmodern seperti sekarang ini. Kedua, karena perkembangan perubahan perilaku konsumen yang perlu dipahami oleh para pelaku UMKM agar mereka dapat memproduksi produk yang benar-benar sesuai dengan kebutuhan dan keinginan pasar. Ketiga, karena iklim persaingan produk-produk yang dihasilkan para pelaku UMKM cenderung makin ketat, sehingga membutuhkan langkah terobosan dari pelaku UMKM itu sendiri untuk dapat memanfaatkan internet dan TI (meski pada tingkat yang elementer) sebagai media pemasaran produk mereka.

\section{METODE PENGABDIAN MASYARAKAT}

Kegiatan ini dilaksanakan dengan cara melakukan sosialisasi dan mengembangkan diskusi interaktif dua arah yang dialogis untuk memperoleh titik pemahaman yang benar-benar mendalam. Dalam kegiatan pengabdian ini, menurut rencana ada tiga materi pokok yang akan disampaikan, yaitu: (1) Mengenali karakteristik dan perkembangan perilaku konsumen di era postmodern. (2) Arti penting dan pemanfaatan TI dan internet dalam pemasaran produk UMKM. (3) Strategi pengemasan produk UMKM yang berorientasi pada tuntutan konsumen di era postmodern.

Kelompok sasaran dari kegiatan ini adalah pelaku UMKM di Kabupaten Tuban. Adapun jumlah peserta yang diikutsertakan dalam kegiatan sosialiasi ini sebanyak 50 
pelaku UMKM. Lokasi kegiatan sosialisasi dilakukan di Kabupaten Tuban. Di mana lokasi pasti kegiatan pelatihan akan didiskusikan terlebih dahulu dengan Dinas Koperasi dan UMKM Kabupaten Tuban. Dalam kegiatan pengabdian kepada masyarakat kali ini sengaja dipilih dilaksanakan di Kabupaten Tuban dengan pertimbangan di daerah tersebut masih banyak pelaku UMKM yang belum memahami pergeseran perilaku dan karakteristik konsumen di era postmodern.

Indikator keberhasilan dari pelaksanaan pengabdian kepada masyarakat ini adalah: (1) Sejauhmana peserta memahami perubahan karakteristik dan tuntutan konsumen di era postmodern. (2) Sejauhmana pelaku UMKM memahami arti penting TI dan internet sebagai media pemasaran produk UMKM. (3) Seberapa jauh pelaku UMKM memahami strategi pengemasan produk yang berorientasi tuntutan konsumen di era postmodern.

Metode pelaksanaan yang dilakukan dalam pengabdian masyarakat menguraikan tahapan-tahapan yang dilakukan mulai dari persiapan pelaksanaan dan finalisasi laporan, serta menawarkan penyelesaian persoalan terkait kendala pengembangan UMKM. Metode pelaksanaan yang dilakukan sebagai berikut:

\section{Tahap 1 Persiapan}

Melaksanakan prosedur perijinan yang ditujukan kepada Dinas Koperasi dan UMKM. Melakukan kunjungan ke lokasi subyek. Diawali dengan melakukan kunjungan ke Dinas Koperasi dan UMKM guna mendata para pelaku UMKM yang menjadi subyek dalam kegiatan ini. Melakukan sosialisasi ke Dinas Koperasi dan UMKM dan mengkoordinasikan para pelaku UMKM untuk ikut serta dalam pelaksanaan pelatihan dan pendampingan yang ada. Mempersiapkan materi pelatihan dan pendampingan.

\section{Tahap 2 Pelaksanaan}

Melaksanaan kegiatan berupa diskusi interaktif sebanyak 1x yang akan dibagi menjadi 3 sesi materi yaitu:
Dr. Bagong Suyanto : Mengenali Karakteristik Dan Perkembangan Perilaku Konsumen Di Era Postmodern.
Dr. Sutinah, MS : Arti Penting Dan Pemanfaatan TI Dan Internet Dalam Pemasaran Produk UMKM.

Ratna Azis Prasetyo, S.Sosio., M.Sosio: Strategi Pengemasan Produk UMKM Yang Berorientasi Pada Tuntutan Konsumen Di Era Postmodern.

Novri Susan, Ph.D : Metode Dan Strategi Branding Produk UMKM Melalui Teknologi Digital

Tahap 3 Finalisasi: Penyusunan laporan kegiatan Penyusunan laporan keuangan, Persiapan seminar

\section{HASIL DAN PEMBAHASAN}

Kegiatan ini dilakukan dengan mengacu dan memahami pemikiran Manuel Castells, seorang ahli yang membahas tentang informasionalisme dan perkembangan masyarakat jaringan. Castells adalah figur sentral yang membahas disorganisasi modernitas, dan 
merupakan teoritikus ilmu sosial yang menjembatani proses transisi perkembangan teori modernitas ke teori globalisasi dan teori postmodern. Komputer dan aliran informasi, dalam pandangan Castells telah mengubah dunia dan menimbulkan berbagai masalah sosial-ekonomi serta budaya yang menjadi ciri masyarakat modern kontemporer atau masyarakat post-industrial. Castells diakui sebagai salah satu teoritikus masyarakat informasi setelah menerbitkan trilogi bukunya yang terkenal: The Information Age: Economy, Society and Culture, yang terdiri dari 3 volume, yaitu Volume 1: The Rise of Network Society (1996), Volume 2: The Power of Identity (1997), dan Volume 3: End of Milleniium (1998).

Castells saat ini menjabat sebagai seorang Profesor sosiologi sekaligus Profesor perencanaan kota dan daerah pada Universitas of California, Berkeley. Castells lahir di Spanyol, kemudian belajar di Paris dan memulai karir akademis di University of Paris. Pada awalnya, Castell lebih banyak menulis buku tentang persoalan perkotaan, seperti The Urban Question (1977), Class, City and Power (1978) dan The City and the Grassroot (1983). Namun, di saat yang sama dan dalam perkembangannya kemudian, Castells lebih tertarik menyoroti perubahan sosial-ekonomi masyarakat modernitas kontemporer yang ia yakini terkait dengan munculnya paradigma teknologi baru selama dua abad terakhir, yaitu teknologi informasi dan komunikasi, serta teknologi biologi yang berbasis ilmu pengetahuan. Selain triloginya yang terkenal tentang perkembangan masyarakat jaringan, Castells pada tahun 2001 kemudian menerbitkan buku The Internet Galaxy: Reflections on Internet Business and Society.

\section{Relevansi Bagi UMKM}

Ketika perkembangan masyarakat dan dunia usaha makin diwarnai arti penting informasi dan pengelolaan informasi, maka tidak bisa tidak para pelaku UMKM yang ingin tetap survive dalam iklim persaingan yang makin ketat, mereka harus bersedia memanfaatkan teknologi informasi dan internet sebagai media untuk mempromosikan produk-produk yang mereka hasilkan.

Bagi pelaku UMKM, pemanfaatan teknologi informasi dan internet menjadi penting untuk dikuasai, karena di era global seperti sekarang yang namanya batas-batas geografis wilayah sudah tidak lagi relevan, dan produk-produk global dari mana pun akan bisa masuk ke pasar nasional. Dalam rangka tetap menjaga kontinuitas usaha yang ditekuni dan untuk menembus pangsa pasar yang lebih besar, maka kegiatan pelatihan dan pendampingan bagi pelaku UMKM di bidang penguasaan teknologi informasi penting untuk dilakukan.

Kegiatan pengabdian kepada masyarakat yang dilakukan Departemen Sosiologi FISIP Universitas Airlangga tahun 2018 dilaksanakan di Kabupaten Tuban dengan tujuan untuk membantu dan meningkatkan pengetahuan ibu-ibu pelaku UMKM untuk dapat memanfaatkan perkembangan teknologi informasi dan internet bagi peningkatan pemasaran produk yang mereka hasilkan.

Sebagai bagian dari pelaku UMKM, disadari salah satu keterbatasan yang dihadapi ibuibu pelaku UMKM di Kabupaten Tuban adalah kurangnya akses mereka pada pasar dan 
iklim persaingan yang makin kompetitif. Untuk membantu ibu-ibu pelaku UMKM dapat bertahan dan bahkan mengembangkan pemasaran produk mereka, oleh sebab itu perlu dilakukan sosialisasi tentang peran teknologi dan internet dalam meningkatkan pemasaran produk UMKM.

Dalam kegiatan sosialisasi, ada empat materi yang disampaikan, yaitu: Mengenal fungsi teknologi informasi dan internet untuk mendongkrak pemasaran produk UMKM disampikan oleh Ratna Azis Prasetyo, S.Sos., M.Si, Inovasi dan upaya memahami selera konsumen oleh Dr. Bagong Suyanto, Pemberdayaan peran perempuan di era masyarakat digital oleh Dr. Sutinah, dan Metode dan strategi branding produk UMKM melalui teknologi digital oleh Novri Susan, Ph.D.

Kegiatan sosialisasi dilaksanakan di Kantor Kecamatan Kerek Kabupaten Tuban. Acara sosialisasi dihadiri sekitar 50 ibu-ibu pelaku UMKM, baik di bidang konveksi, garmen, asesoris, dan lan-lain yang semuanya merupakan pelaku usaha mikro dan kecil. Kegiatan sosialisasi dan diskusi berlangsung kurang-lebih 3 jam. Acara sosialiasi dilaksanakan lesehan di ruang Lantai Kantor Kecamatan yang bersih.

Selama proses sosialiasi, antusiasme ibu-ibu peserta terlihat sangat tinggi. Beberapa pertanyaan yang dilontarkan ibu-ibu peserta sosialisasi adalah: Apa program dalam teknologi informasi, khususnya gadget yang bisa dimanfaatkan untuk promosi produk UMKM? Bagaimana caranya membuat situs untuk memasarkan produk UMKM?Apakah pembuatan situs untuk memasarkan produk UMKM harus membayar ataukah gratis. Situs apa yang tidak mengharuskan pembuat membayar? Bagaimana caranya membuat gambar atau memasukkan foto produk UMKM dalam situs di internet? Kendala yang dihadapi pelaku UMKM adalah soal keterbatasan dana. bagaimana caranya membuat produk yang inovatif, dengan dana yang terbatas? Sebagian ibu-ibu peran mereka dalam UMKM adalah sebagai tenaga pembantu dari usaha yang ditekuni suaminya. Bagaimana caranya meyakinkan suami tentang usulan produk UMKM yang inovatif dari ibu-ibu?

Dari hasil sosialisasi dan diskusi yang dilaksanakan, sebagian besar ibu-ibu peserta sosialisasi umumnya puas dan tertarik untuk mengembangkan apa yang disampaikan para nara sumber. Sebagian ibu-ibu mengusulkan ada tindak-lanjut kegiatan pengabdian dengan aktivitas yang lebih konkrit, yakni melatih langsung ibu-ibu tentang cara membuat situs dan memanfaatkan gadget untuk memasarkan produk UMKM

\section{PENUTUP}

\section{Simpulan dan Saran}

Perkembangan teknologi digital telah merubah selera konsumen. Kondisi ini menyebabkan para pelaku UMKM lokal harus bersaing secara global. Kegiatan pengabdian ini telah melakukan pemberdayaan terhadap pelaku UMKM lokal agar mampu merespon pergeseran selera konsumen. Dari hasil kegiatan yang dilakukan sebagian besar para pelaku usaha ini memiliki respon yang positif dan menginginkan adanya tindak lanjut dari aktivitas pemberdayaan seperti melakukan pelatihan dan pendampingan dalam pemasaran produk melalui teknologi digital. 


\section{DAFTAR PUSTAKA}

Castells, Manuel. 1996. The Rise of The Network Society, Volume 1 of The Information Age: Economy, Society and Culture. Oxford: Blackwell Publishing.

1997. The Power of Identity, Volume 2 of The Information Age: Economy, Society and Culture. Oxford: Blackwell Publishing.

1998. End of Millennium, Volume 3 of The Information Age: Economy, Society and Culture. Oxford: Blackwell Publishing.

2001. The Internet Galaxy: Reflections on the Internet, Business, and Society. Oxford: Blackwell Publishing. 